DR DAVID ROBIE is director of the Pacific Media Centre (AUT).

\section{Bearing witness in 40 years of Greenpeace chronicles}

Rainbow Warrior Mon Amour: Trente ans de photos aux côtés de Greenpeace, by Pierre Gleizes. Paris: Glenart, 2011, 379 pp. ISBN 9782723484558

Warriors of the Rainbow: A chronicle of the Greenpeace movement from 1971 to 1979 , by Robert Hunter [40th anniversary edition]. Perth: Greenpeace and Freemantle Press, 2011, 451pp. ISBN 978-1921888809.

$\mathbf{M}_{\text {vered copy of the late Robert }}^{\text {DOG-EARED yellow-co- }}$ Hunter's Warriors of the Rainbow still has pride of place among my bookshelves. It was inspirational in many respects before I embarked on Rainbow Warrior I's journey to the Marshall Islands in May 1985 which led to the bombing in Auckland's Waitemata Harbour two months later and my own book Eyes of Fire about that ill-fated humanitarian voyage, so very different from most Greenpeace campaigns.

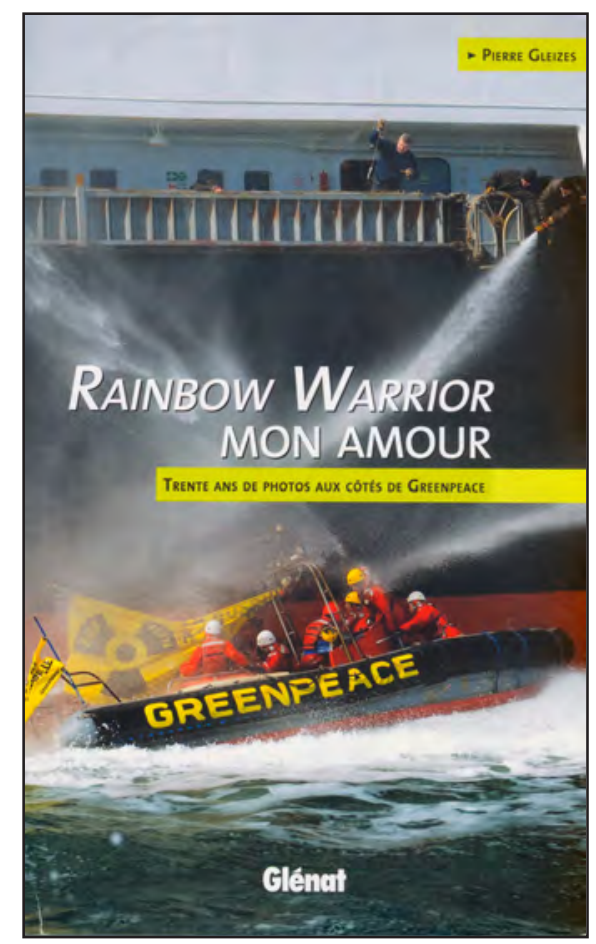

One of the original Greenpeace environmental crusaders, journalist Hunter provided a powerful and insightful tale of the Canadian birth and early years of the global movement 'from Amchitka to Moruroa'. Even before the corporate trend to mission statements, Greenpeace had one provided by the Cree Indians and popularised by Hunter.

It told the story of when environmental disaster threatened, "the medicine men were sent forth to deal with it' (Hunter, 2011, p. 15). Only when they failed to set things right 


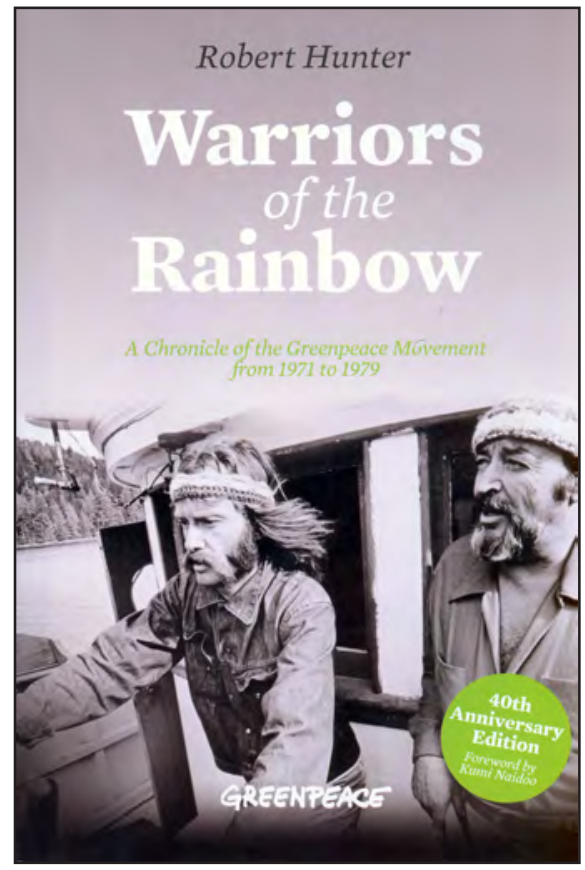

on Earth did the warriors emerge. The prophecy of the warriors was related by a grandmother named Eyes of Fire and this inspired the title of my own book (1986, 2005).

The original Warriors narrative gave a glowing account of the early Greenpeace campaigners sailing around the Pacific in the Phyllis Cormack, James Bay and Vega (Hunter, p. 6) 'consuming excessive amounts of recreational drugs, bickering over internal politics, risking their lives, developing arguments about whales being sentient beings and staving off bankruptcy', as current Greenpeace international executive director Kumi
Naidoo puts it in this 40th anniversary edition.

This publication includes an additional chapter (author's note) discovered in 2011 among his papers, six years after he died in May 2005, and supposedly written about a decade after the book was first published. It was a rather prophetic statement about the state of the global environment. Hunter recalled that during the first seven years of the movement, he experienced many miracles as part of what he termed the 'Greenpeace phenomena'.

With the launching of the Greenpeace movement in the West Coast of Canada, a trace of long dormant shamanistic magic wafted over the continent and ocean that Europeans had long ago swarmed across. This dew of magic moved backward over the checkerboard plains where today only a handful of buffalo survive. It passed the nuclear reactors leaking into the Great Lakes. It skudded through the carbon dioxide clouds and above the acid rain-eaten forests, over the Love Canal and across the Sea of Slaughter in the St Lawrence, whispering over the bloody ice packs of Labrador. The magic crossed the lonely North Atlantic where you can voyage for a week now without seeing a single whale, and reaching at last the shores of Europe, whence the carnage and poisoning began, like the 
ghost of the Red Man holding up his hand and saying: No more! (p. 14).

But, as Hunter noted, during the Greenpeace campaigns, 'miracles were not only commonplace-we got quite a few of them on film and on tape' (p. 15).

This sleek new edition contrasts with the bulky original version (which was devoid of illustrations) and includes 16 pages of archival iconic images in black and white and colour from 1971 to 1977, including two of Paul Watson who broke away and formed the more radical Sea Shepherd Conservation Society.

It is the images that drew me to Pierre Gleizes' own new book, Rainbow Warrior Mon Amour, a play on a book by Kon Tiki raft adventurer and later nuclear-free campaigner Swedish-born Bengt Danielson and his French wife, Maire-Therese. The Danielssons chronicled the nuclearfree struggles and tribulations of the Tahitians in Moruroa Mon Amour, Moruroa being the main testing atoll for France's force de frappe.

This book also chronicles Greenpeace environmental adventures, this time for three decades through the lens (and words) of French photojournalist Pierre Gleizes. I never actually met Gleizes, but had long admired his work and used three of his pictures from Canadian, Russian and Spanish campaigns in Eyes of Fire.

Greenpeace was launched in Vancouver, Canada, in September 1971. Nine years later, at the age of 23 , Gleizes embarked on the campaign ship Rainbow Warrior as a crew member and photographer.

He was a witness to many of the non-violent campaigns at the heart of the environmental movement. And through his photography, he was a key contributor to international public awareness.

His images have often been more effective in denouncing environmental violations than words. As well as working for Greenpeace, Gleizes was a news photographer for Associated Press for nine years and for other media.

Gleizes has been on the scene campaigning against the culling of whales and slaughter of pup seals, struggle against pollution, combating pirate fishing boats, exposing the impact of climate change and challenging the nuclear industry and bomb tests.

Rainbow Warrior Mon Amour tells of his adventures on board the Rainbow Warrior, Sirius and Esperanza. He relates his experiences with humour, packed with insight and commitment to the environment.

An intriguing feature of his book 


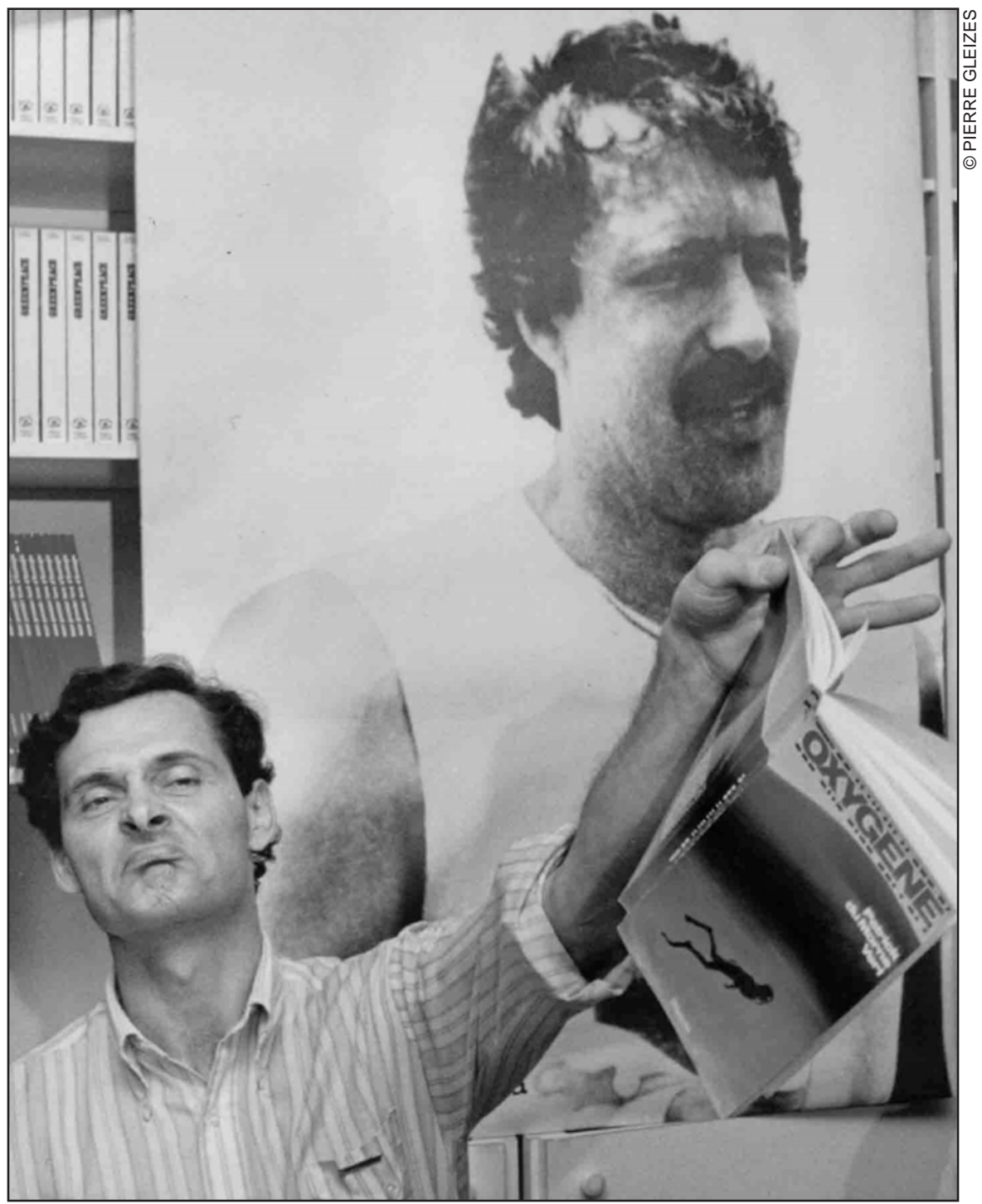

Yves Lenoir, a French spokesman for Greenpeace, grimaces as he holds a copy of Mission Oxygène about the Rainbow Warrior bombing on 10 July 1985. In the backgrond is a portrait of Portuguese photographer Fernando Pereira, who drowned after the second explosion on the ship. 
is a chapter devoted to insights from four French-language books about the bombing by French secret agents in Auckland Harbour on 10 July 1985 while preparing for anti-nuclear protests off Mororoa Atoll. (Nuclear tests were eventually abandoned by France in 1996.)

Mission Oxygène by Patrick du Morne Vert (1987) was believed by many readers to be an 'investigation' by a former DGSE secret agent. But du Morne Vert (writing under the pseudonym Patrick Amory) denied this, saying in spite of the appearance it was a 'work of fiction' although many key protagonists in the so-called Greenpeace affair had been named (p. 147).

Carnet secrets d'un nageur de combat: du Rainbow Warrior aux glaces de l'Arctique, by Alain Mafart (with Jean Guisnel, 1999): 'Ten years after its appearance, I found the courage to read this book by one of the two French secret agents, tried and found guilty in New Zealand for the attack on the Rainbow Warrior. However, after reading this book I found it was the only one that touched my heart' (p. 148).

Agent secrète, by Dominique Prieur (with Jean-Martie Pontaut, 1995). Posing as Mafart's wife on a honeymoon, Prieur proudly declared she had made two visits to the Rainbow
Warrior in the Netherlands long before the bombing. But Gleizes says she was wrong on both counts-she probably meant the MV Greenpeace because the Rainbow Warrior was in Jacksonville, Florida, at that time (p. 152).

Un amiral au secret, by Admiral Pierre Lacoste, director of the DGSE at the time of the state terrorist attack. Although this book did not confirm outright then President François Mitterand's blessing for the operation, it has been confirmed since this book by other sources (p. 154).

'This massive political mistake,' reflects Gleizes, 'was mostly due to the fact that the French authorities did not understand what Greenpeace was. In all those books, this ignorance remains utterly shocking. If they had bothered to learn more about us, they would never have felt the urge to plan this unimaginable act. We were only a bunch of noisy people - not so well organised! In 1982, the Russians were much smarter in dealing with Greenpeace.

'A few years ago, when I read about the Greenpeace affair in the book, L'Histoire de France pour les nuls (French history for Dummies), I realised the scale of impact this sad event had on my country.' 
References

Hunter, R. (1979). Warriors of the Rainbow Warrior: A chronicle of the Greenpeace Movement. New York: Holt, Rinehart and Winston.

Robie, D. (2005). Eyes of Fire: The last voyage of the Rainbow Warrior [Memorial Edition]. Auckland: Asia Pacific Network.

Robie, D. (1986). Eyes of Fire: The last voyage of the Rainbow Warrior. Auckland: Lindon.

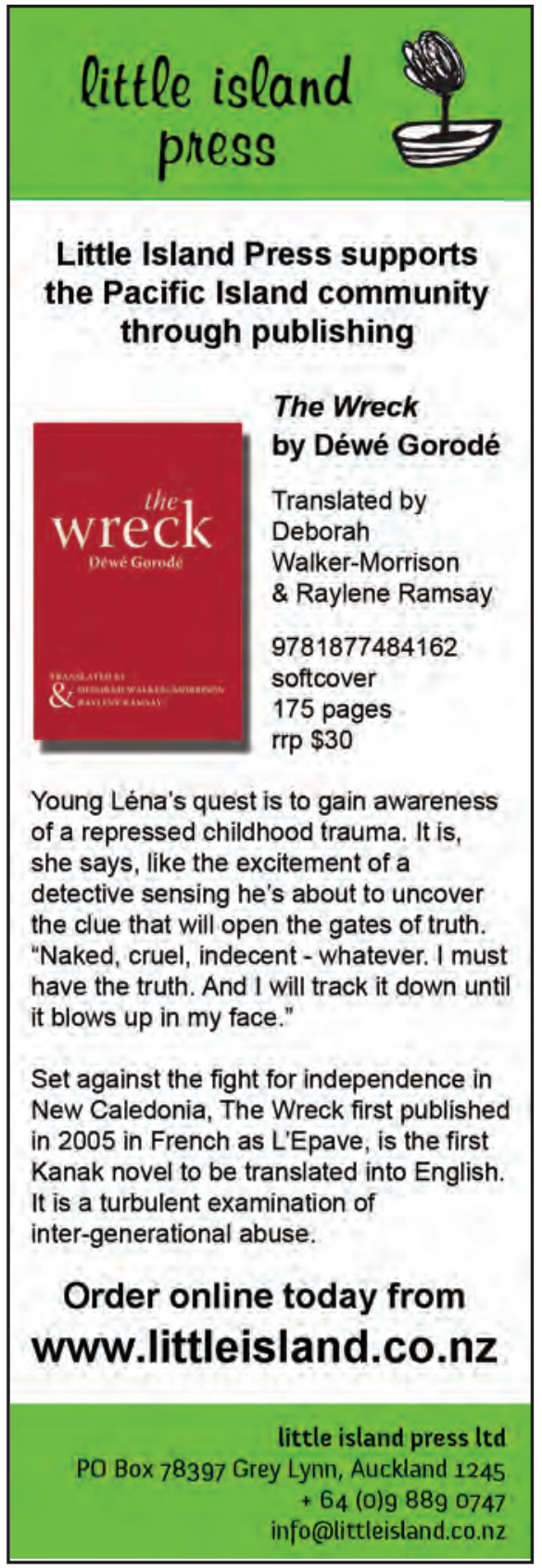

PACIFIC JOURNALISM REVIEW 18 (1) 2012237 